\title{
Design of a Completely New First Year Engineering Program at the University of Saskatchewan - Part II
}

\author{
Joel B. Frey, Sean Maw, Susan Bens, Jim Bugg, and Bruce Sparling \\ University of Saskatchewan \\ Corresponding Author: sean.maw@usask.ca
}

\begin{abstract}
Over the last three years, the University of Saskatchewan's College of Engineering has embarked upon a complete redesign of its first year common program. This project started from a blank slate and posed the question, "If we could design any first year program that we wanted, what would we create?" The goal is to offer a first year program that excites, engages, inspires, and holistically prepares students for learning in subsequent years. At CEEA 2018, Phase I of this project was reviewed with a focus on the content of the new first year. This year, the focus is on the structure of the proposed program and how it aims to satisfy programmatic design objectives.

The proposed first year program is highly modular, allowing for more intentional uses of time during the academic year. Course duration and intensity vary and are selected to best serve student learning, rather than conform to the traditional academic schedule. To provide more timely and targeted feedback, summative assessments occur throughout each term allowing course scheduling to extend into the traditional end-of-term final exam period. This paper presents the current structural design of the new first year and the rationale for its significant features.

Some of the program design objectives that have been facilitated by this structure include:

- strategic sequencing of learning with opportunities to integrate and reinforce essential skills,

- multiple, individualized opportunities for students to stumble and recover,

- holistic balancing of content and pacing for better student wellbeing, and

- comprehensive, well-timed exposure to wide-ranging programmatic choices for students.

Throughout this project, the program structure has evolved continuously. This paper will describe the development process, the challenges faced in that process, and the lessons learned. The paper will conclude by describing the current status of the project, and the focus of work currently being undertaken to prepare for implementation.
\end{abstract}

Keywords: first year, engineering, program, design, integrated curriculum, planning, accelerated courses, Saskatchewan

\section{INTRODUCTION}

For the past three years, the University of Saskatchewan's College of Engineering has been steadily working towards the implementation of a completely new first year program (FYP). The vision for the redesigned FYP is to attract excellent students to our College from Saskatchewan, Canada and beyond, and to excite, engage and inspire our students, while preparing them holistically for the challenges to come in later years.

The project has been broken into three phases:

- Phase I - determination of first year graduate attributes,

- Phase II - development of program structure and delivery methods, and

- Phase III - development of course material.

At CEEA 2018 [1], we reported on the results of Phase I and the process by which the desired first year graduate attributes were determined. This involved reviews and comparisons of first year engineering programs across Canada and detailed consultation of students, faculty and staff within the College of Engineering and across the University of Saskatchewan campus. The final deliverable of Phase I was a 100+ page document outlining the knowledge, skills, experiences and attitudes/beliefs (KSEA), across 23 categories, that the new program would be designed to develop in students by the end of first year.

While Phase I focused on the "what" of first year engineering, Phase II of the project has focused on the "how". More specifically, Phase II has focused on the development and refinement of an innovative delivery model for the content identified in Phase I. This model allows for the intentional sequencing and integration of material and experiences that has not been seen with traditional delivery models.

The process employed in Phase II, and the resulting model, constitute the focus of this paper.

\section{PHASE II METHODOLOGY}

The focus of Phase II has been determining an effective delivery model for the new FYP, including both the weekly schedule and the arrangement of courses by semester, or what we have taken to calling the "structure" of the program. 


\subsection{Initial Assumptions}

We have maintained our project design philosophy of starting each design cycle from as much of a "blank slate" as possible. Phase I of the project yielded the desired first year graduate attributes and this list became the clay from which we began sculpting the program structure. We set out with the objective of including all topics identified as necessary by the stakeholders, with time allotments approximately proportionate to the distribution of the number of graduate attributes identified for each topic. We also sought to keep weekly contact hours at or below those of the existing first year program. Otherwise, we initially did not impose any constraints and viewed the fall and winter semesters as two blank canvasses upon which we could arrange delivery of the necessary topics as we saw fit to best facilitate student learning outcomes. To be clear, "no constraints" meant that we did not initially consider any of the following potential restrictions:

- Scheduling constraints (no requirement for 13 week courses followed by a final exam period, and no assumptions on duration or intensity of individual courses),

- Physical/Facility constraints (classrooms, laboratory space, and equipment),

- Personnel constraints (assignment of duties, restrictions imposed by collective agreements),

- Assessment constraints (the need for final exams, timing of reporting of grades),

- Financial constraints (tuition and/or fees), and

- Academic constraints (accreditation, credit units, transfer programs).

While it may seem foolish to ignore these important considerations, many of these constraints are often the factors that prevent real change and program improvement from occurring, or even from being considered. Our approach allowed for a design based purely on what would work best pedagogically and that would best realize the goals of the program (discussed in Section 3).

\subsection{Structural Refinement}

The existing FYP at USask features traditionally paced courses which run 12-13 weeks, with a break week near the midpoint, and finishes with a roughly 3 week exam period. In contrast to this, early versions of the proposed program structure featured very intensive, accelerated courses, which included a similar number of contact hours as a traditional course, condensed to a duration of only 3-6 weeks. This allowed for a minimum number of concurrent subjects and logical sequencing of material, leading to immediate application of mathematical and scientific concepts in engineering science and design courses (justin-time learning [2]).

To continue with the sculpting analogy, a sculptor may begin with a beautiful mental model which, for example, may have a very narrow base and an asymmetrical design. When realized physically, the creation topples over due to the practical constraint of gravity and must be refined, compromising on some ideals. This mirrors the experience of our design team as we began consulting stakeholders and applying various constraint filters, such as facility and personnel availability, to the proposed structure. Facility and personnel constraints were analyzed by completing detailed scheduling of the entire curriculum, while the other constraints listed above were introduced through multiple rounds of consultation with academic, administrative, and regulatory stakeholders.

During this process, many of these constraints led to refinements of the program structure. The most profound impact came from facility constraints. To meet our objective of maximizing active learning opportunities such as group work and laboratory experiments for the entire expected first year cohort (600 students), most courses became drawn out in duration with a corresponding reduction in intensity. However, many constraints, such as the existing tuition model and the assessment philosophy requiring a final exam period, were challenged during this process and it was found that some of these "constraints" were not as rigid as initially assumed. Various units on campus have collaborated to steadily work toward creative solutions to allow the program to best serve the students. This has validated our "blank slate" design process. Simply asking, "What would work best?", instead of asking, "What would work best within the system we all take for granted?", has afforded the design team creativity that would have otherwise been stifled.

As high-level course development work has begun, engagement of instructors and subject matter experts from all academic departments involved has led to further refinements of the program's structural details. Changes get smaller and more specific with each round of consultation as we approach a steady-state. The revisions implemented as we have "failed early and failed often" [3] have created a more robust and implementable design.

\section{PROPOSED PROGRAM STRUCTURE}

Figures 1 and 2 on the following pages illustrate the latest evolution of the structural design for the new FYP. Tables 1 and 2 describe some of the salient course details. The top two rows of the schedules show weeks and months. Below that, labeled horizontal bands represent the modular courses. The width of a band (course) reflects the period of time over which the course runs. For example, in Fig. 1, Linear Algebra runs from Week 9 through Week 14. The height of a band reflects the intensity of a course. The height of an average band (e.g. Calculus I) represents approximately $7 \mathrm{hrs} / \mathrm{wk}$ of class time, including lectures, labs, and tutorials. Programming is double the standard intensity, and the Engineering Discipline Labs are approximately 4 times that intensity. 


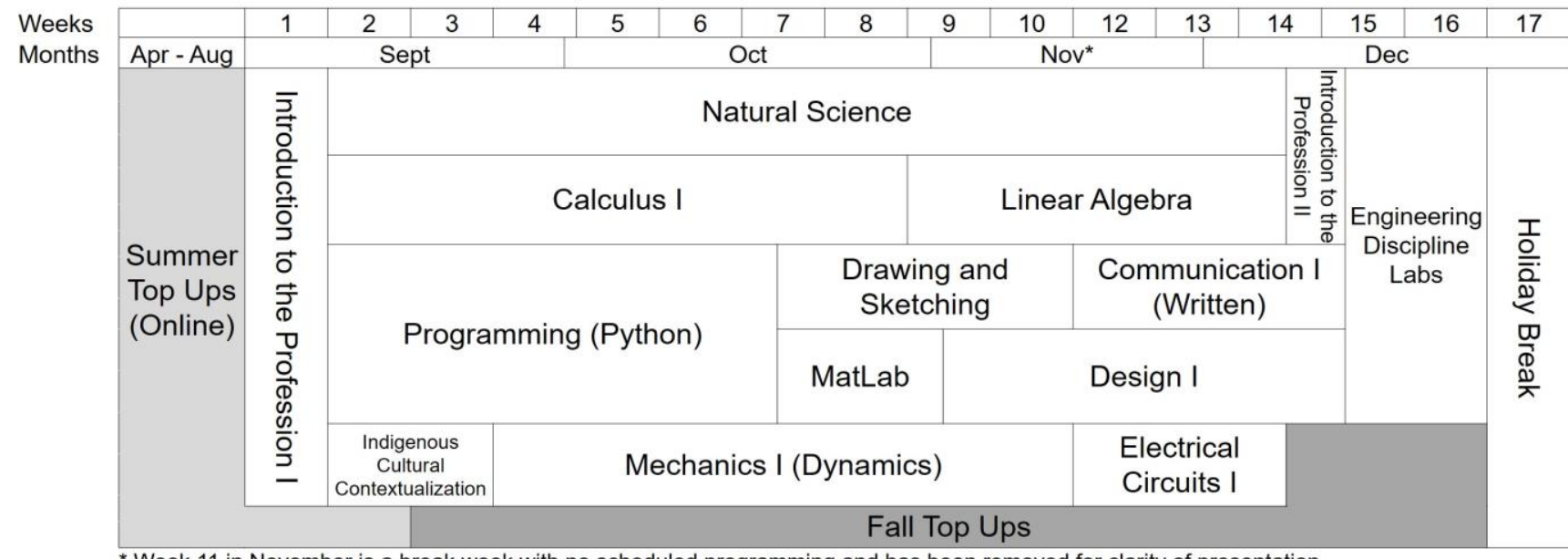

* Week 11 in November is a break week with no scheduled programming and has been removed for clarity of presentation

Figure 1. Proposed program structure for first term.

Table 1: Contact hours and basic details for first term courses in the proposed FYP.

\begin{tabular}{|c|c|c|c|c|c|}
\hline \multirow{2}{*}{ Course } & \multicolumn{4}{|c|}{ Contact Hours } & \multirow{2}{*}{ Notes } \\
\hline & Lect. & Lab. & Tut. & Total & \\
\hline Calculus I & 31.5 & 9 & 9 & 49.5 & An introduction to differential and integral calculus at the conceptual level. \\
\hline $\begin{array}{c}\text { Communication I } \\
\text { (Written) }\end{array}$ & 15 & 0 & 2.5 & 17.5 & $\begin{array}{l}\text { A written technical communications course supporting completion of } \\
\text { deliverables in Design I. Small class sizes allow lectures to be used as labs } \\
\text { when needed. }\end{array}$ \\
\hline Design I & 12 & 15 & 5 & 32 & $\begin{array}{l}\text { An introduction to design with a common project for all students; includes } \\
\text { elements of entrepreneurship, project management, leadership, and group } \\
\text { dynamics. }\end{array}$ \\
\hline $\begin{array}{l}\text { Drawing \& } \\
\text { Sketching }\end{array}$ & 0 & 15 & 2.5 & 17.5 & $\begin{array}{l}\text { A manual graphical communication course where labs serve as instructional } \\
\text { time. }\end{array}$ \\
\hline $\begin{array}{l}\text { Electrical } \\
\text { Circuits I }\end{array}$ & 15 & 0 & 3 & 18 & $\begin{array}{l}\text { An introduction to basic electrical circuits, supporting the electrical and } \\
\text { computer engineering components of the Engineering Discipline Labs. }\end{array}$ \\
\hline $\begin{array}{c}\text { Engineering } \\
\text { Discipline Labs }\end{array}$ & 24 & 24 & 8 & 56 & $\begin{array}{l}\text { Intensive, one day introductions to each USask Engineering program, i.e. } \\
\text { students rotate through all } 8 \text { programs over the } 8 \text { days. }\end{array}$ \\
\hline Fall Top Ups & 0 & 0 & 63 & 63 & $\begin{array}{l}\text { Optional tutorial time used by students to achieve competence in learning } \\
\text { outcomes missed during courses or to improve marks when competence was } \\
\text { achieved, thereby promoting skills in self-directed learning. }\end{array}$ \\
\hline $\begin{array}{l}\text { Indigenous } \\
\text { Cultural } \\
\text { Contextualization } \\
\end{array}$ & 7.5 & 7.5 & 0 & 15 & $\begin{array}{l}\text { A cultural foundation course that will allow for contextualized subsequent } \\
\text { inclusion of Indigenous examples in the curriculum and an introduction to the } \\
\text { importance of inclusivity and intercultural competencies in engineering. }\end{array}$ \\
\hline $\begin{array}{l}\text { Introduction to } \\
\text { the Profession I }\end{array}$ & 7.5 & 10.5 & 1 & 19 & $\begin{array}{l}\text { An orientation to the College, University, and profession, as well as study } \\
\text { skills, life skills, professionalism, ethics, and some health and safety training. }\end{array}$ \\
\hline $\begin{array}{l}\text { Introduction to } \\
\text { the Profession II }\end{array}$ & 6 & 0 & 2 & 8 & $\begin{array}{l}\text { A course featuring more depth on the topics covered in Introduction to the } \\
\text { Profession I, with some opportunity for reflection. }\end{array}$ \\
\hline Linear Algebra & 19.5 & 7.5 & 5 & 32 & $\begin{array}{l}\text { An applied introductory linear algebra course that builds on the Programming } \\
\text { and Matlab courses, allowing students to use programming to solve a variety } \\
\text { of types of linear algebra problems including systems of linear equations. }\end{array}$ \\
\hline MatLab & 0 & 9 & 2 & 11 & $\begin{array}{l}\text { A short and intense introduction to the fundamentals of Matlab, that builds on } \\
\text { the Programming course. Labs serve as instructional time. }\end{array}$ \\
\hline $\begin{array}{l}\text { Mechanics I } \\
\text { (Dynamics) }\end{array}$ & 22.5 & 12 & 10 & 44.5 & $\begin{array}{l}\text { A first year particle dynamics course that builds on the Physics Summer Top } \\
\text { Up and high school physics (projectile motion). }\end{array}$ \\
\hline Natural Science & 36 & 24 & 12 & 72 & $\begin{array}{l}\text { A unique survey course of the physical sciences (Chemistry, Biology, Physics, } \\
\text { Geology) lasting } 3 \text { weeks ( } 18 \text { contact hours) per science, to compare and } \\
\text { contrast between the sciences and each related engineering discipline. }\end{array}$ \\
\hline Programming & 22.5 & 19.5 & 6 & 48 & An introductory computer programming course for engineers, using Python. \\
\hline Summer Top Ups & 0 & 0 & 15 & 15 & $\begin{array}{l}\text { Online, mastery-model modules covering key high school-level concepts in } \\
\text { Calculus, Algebra, Chemistry, Physics, Writing, Reading Comprehension and } \\
\text { Indigenous History. To be completed by students before September, with } \\
\text { some support time for completion during the first few weeks of school. }\end{array}$ \\
\hline
\end{tabular}




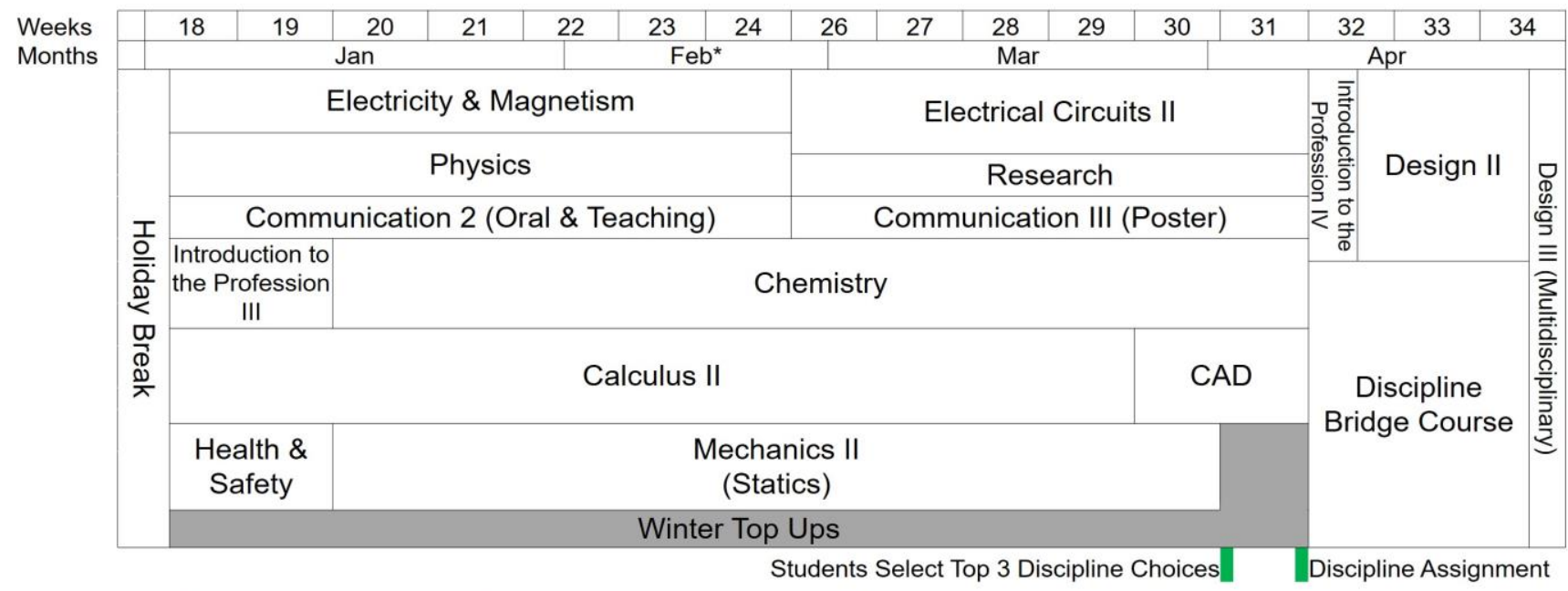

* Week 25 in February is a break week with no scheduled programming and has been removed for clarity of presentation

Figure 2. Proposed program structure for second term.

Table 2: Contact hours and basic details for second term courses in the proposed FYP.

\begin{tabular}{|c|c|c|c|c|c|}
\hline \multirow{2}{*}{ Course } & \multicolumn{4}{|c|}{ Contact Hours } & \multirow{2}{*}{ Notes } \\
\hline & Lect. & Lab. & Tut. & Total & \\
\hline CAD & 0 & 12 & 1.5 & 13.5 & $\begin{array}{l}\text { A short introduction to Computer Aided Design, building on manual } \\
\text { Drawing and Sketching. Software TBD. }\end{array}$ \\
\hline Calculus II & 33 & 15 & 11 & 59 & $\begin{array}{l}\text { The sequel to Calculus I: presents differential and integral calculus in } \\
\text { greater depth with expanded tool kits and application difficulty. }\end{array}$ \\
\hline Chemistry & 48 & 27 & 8 & 83 & $\begin{array}{l}\text { A first year chemistry course for engineers that builds on the chemistry } \\
\text { component of the Term } 1 \text { Natural Science course. }\end{array}$ \\
\hline $\begin{array}{l}\text { Communication } \\
\text { II (Oral \& } \\
\text { Teaching) }\end{array}$ & 19.5 & 0 & 4 & 23.5 & $\begin{array}{l}\text { An oral communication course with applications to peer } \\
\text { teaching/mentoring/support, research presentations and Design II. Small } \\
\text { class size allows lectures to be used as labs when needed. }\end{array}$ \\
\hline $\begin{array}{l}\text { Communication } \\
\text { III (Poster) }\end{array}$ & 12 & 0 & 2.5 & 14.5 & $\begin{array}{l}\text { An integrative communication course that combines written, graphical and } \\
\text { oral communication skills and supports the poster presentation deliverable } \\
\text { of the Research course. }\end{array}$ \\
\hline Design II & 16.5 & 18 & 5 & 39.5 & $\begin{array}{l}\text { A second common design class with project topics drawn from each of the } \\
8 \text { USask engineering programs. }\end{array}$ \\
\hline Design III & 0 & 7 & 0 & 7 & A one day, multidisciplinary design challenge. \\
\hline $\begin{array}{l}\text { Discipline Bridge } \\
\text { Course }\end{array}$ & 39 & 0 & 7 & 46 & $\begin{array}{l}\text { A bridging course designed to give students a head start in the second year } \\
\text { of their chosen discipline. }\end{array}$ \\
\hline $\begin{array}{l}\text { Electric Circuits } \\
\text { II }\end{array}$ & 25.5 & 6 & 5.5 & 37 & $\begin{array}{l}\text { The sequel to Electric Circuits I and Electricity and Magnetism: introduces } \\
\text { RL and RC circuit analysis and other topics in Electrical Engineering. }\end{array}$ \\
\hline $\begin{array}{c}\text { Electricity \& } \\
\text { Magnetism }\end{array}$ & 21 & 9 & 7 & 37 & An introductory course on electricity and magnetism. \\
\hline Health \& Safety & 0 & 12 & 0 & 12 & A series of online safety training modules. \\
\hline $\begin{array}{l}\text { Introduction to } \\
\text { the Profession III }\end{array}$ & 7.5 & 3 & 1 & 11.5 & $\begin{array}{l}\text { A third Introduction to the Profession course, which includes an overview } \\
\text { of the role of the humanities and social sciences, allowing for more } \\
\text { informed decisions on upper-year complementary study electives. }\end{array}$ \\
\hline $\begin{array}{l}\text { Introduction to } \\
\text { the Profession IV }\end{array}$ & 4.5 & 0 & 1 & 5.5 & $\begin{array}{l}\text { A fourth Introduction to the Profession course focused on reflection on } \\
\text { professionalism and preparation for summer employment. }\end{array}$ \\
\hline $\begin{array}{c}\text { Mechanics II } \\
\text { (Statics) }\end{array}$ & 34.5 & 10.5 & 11.5 & 56.5 & A particle and rigid body statics course that builds on Dynamics. \\
\hline Physics & 30 & 0 & 7 & 37 & $\begin{array}{l}\text { A physics course that builds on the physics component of the Term } 1 \\
\text { Natural Science course. Lectures are demonstration-based with no labs. }\end{array}$ \\
\hline Research & 16.5 & 6 & 3 & 25.5 & $\begin{array}{l}\text { A genuine first-year research experience with project data from each } \\
\text { engineering discipline and findings presented at a poster symposium. }\end{array}$ \\
\hline Winter Top Ups & 0 & 0 & 31 & 31 & $\begin{array}{l}\text { Optional tutorial time used by students to achieve competence in learning } \\
\text { outcomes missed during courses or to improve marks when competence } \\
\text { was achieved, thereby promoting skills in self-directed learning. }\end{array}$ \\
\hline
\end{tabular}




\subsection{A Coordinated and Integrated Curriculum}

The modular approach of the new FYP facilitates a truly coordinated and integrated curriculum, both in terms of intentionally sequenced material and integration of concepts and applications between concurrent courses. While there is little research comparing the learning outcomes of traditionally paced courses and modular, accelerated courses in engineering specifically, there is a wealth of information available for other subjects [4,5] including the natural sciences [6]. Most studies have found that outcomes from accelerated courses are at least on par with those of courses of traditional length $[7,8,9]$.

Some studies indicate that students in accelerated courses do exhibit an advantage in recall of course concepts immediately after the course when compared with students taking the same course over a longer time period [10]. This is an intuitive result, as the information would be fresh in the minds of the students in the accelerated courses. It was found that this advantage, when observed, faded when students were tested several months after the course [11]. However, the just-in-time learning philosophy we have adopted [2] has led to a sequencing of subjects which is well positioned to promote deep learning, making use of prior learning before it has been forgotten.

One of the best examples of this progressive sequencing is computer programming. Students begin the year with an intensive programming course in Python. Students can then translate their skills into another programming language by immediately jumping into Matlab. Then, with these new skills, students can apply them in virtually every other technical course for the rest of the year. In this way, program-level learning outcomes can be much higher level than those of any one course.

Another example of purposeful sequencing appears in our efforts to respond to institutional and professional priorities related to Indigenization and reconciliation [12]. A cultural contextualization will be established to appropriately set the stage for respectful inclusion of Indigenous content. By placing this course early in the first term, students are prepared for examples of Indigenous design and technologies to be incorporated to greater extents into the rest of the first year curriculum.

Across the FYP, concepts will be purposefully linked to also allow for direct integration between concurrent courses. Concepts in Calculus I will be introduced as needed for application in Dynamics and examples of applications of calculus can be taken directly from Dynamics. Technical communication concepts will be directly tied to concurrent courses, e.g. Communication III with Research. Design II will take advantage of the fact that students will already be placed in disciplines to facilitate the most motivating choices of design projects. Several other opportunities for such integration are embedded in the program structure.
It is worth noting that such a coordinated effort will require an integrated core team of instructors, communicating continuously, between departments and colleges, both during the development of the program and during its delivery.

\subsection{Bridging In and Out of First Year}

The transition to university can be daunting and it is a recognized factor in attrition [13]. Likewise, the jump to disciplinary programs in second year can be abrupt, as students in a common FYP may still be uncertain what discipline they will enter by the end of first year classes. This situation can create prerequisite challenges for engineering programs if students have not taken the "right" electives in first year that match with their ultimate programmatic destinations. A modular program structure can help to address these challenges.

Students arriving to first year are not homogenous. They have different qualities, depths, and breadths of training. So why treat them all the same way by having everyone take the same introductory courses that start at the most introductory levels? With the online "Summer Top Ups", we will set an attainable minimum standard for basic knowledge and skills across a number of fields, i.e. calculus, algebra, physics, writing, reading, chemistry, and Indigenous People's histories. Those at or above the standard will easily be able to show their readiness for first year. For those with one or more areas of weakness, they will have an opportunity to develop competence so that first year instructors can proceed knowing that all students have the same base knowledge and skills in those areas. As such, instructors can avoid boring better prepared students with these materials, and also avoid overwhelming lesser prepared students. Largely consisting of online resources and automated assessments, the Summer Top Ups will help set expectations and prepare all students for a strong start to first year engineering.

Introduction to the Profession courses will address general life skills to better facilitate a smooth transition into the College. This transition support will include ensuring basic competency with word processors and spreadsheets, as well as study skills, time management, stress management, exam writing strategies, learning styles, critical thinking, group dynamics training, dealing with failure, and an internalization of a growth mindset [14].

The bridge out of first year empowers students to succeed in their discipline. Students will have confirmation of their discipline by the end of Week 31 . This timing allows students to become excited about, and better prepared for, second year. Design II will feature discipline specific design projects and the Discipline Bridge Course will be a full course in each student's discipline. While one major goal is to generate enthusiasm for second year among students, the Discipline Bridge Course has turned out to have a very important secondary effect. It is allowing departments to streamline their multi- 
year program offerings. For example, by having their students take another programming course at the end of the FYP, Computer Engineering can include more advanced programming courses in the $2^{\text {nd }}$ and $3^{\text {rd }}$ year of the program. Civil, Geological and Environmental Engineering students will complete Survey Camp before the end of first year.

\subsection{More Informed Decision Making}

We aspire to have zero attrition due to academic failure in our new FYP. However, we ironically aspire to maximize attrition among those who may realize that engineering ultimately is not for them. Instead of having this kind of attrition in $2^{\text {nd }}$ or $3^{\text {rd }}$ year, we want it to happen at the end of the first term, ideally, and by the end of the first year at the latest. We also want to facilitate better decision making in discipline and elective course selection.

Empowering more informed decisions will be accomplished by spending significant time in the first term showing students the features of various engineering disciplines, and comparing and contrasting them with the related physical sciences. The existing FYP does not expose students to a selection of physical sciences until the $2^{\text {nd }}$ term. Furthermore, most students only see a 20 minute sales pitch for each engineering discipline. In the proposed FYP, students will spend an entire day with every engineering discipline before the end of Term 1, concluding with advising sessions in each discipline for those students strongly interested. They will also see every physical science, as well as computer science and mathematics. In those cases, they will explicitly learn about the relationships and differences between related fields, such as chemistry and chemical engineering, engineering physics and physics, and so on. The explicit goal for the Natural Science survey course in Term 1 will be to excite and inspire the students, and to empower them with a skill that bridges disciplines.

By the end of first term, students who remain in engineering will hopefully have a higher level of confidence in their chosen vocation and a better sense of what their disciplinary choice will be. Indeed, in the new curriculum, students will be exposed to course materials in more areas of engineering by the time they need to make their choices in late March.

\subsection{Empowering Life Long Learning}

The Fall and Winter Top Ups will operate in a similar fashion to the Summer Top Ups, insofar as they will allow students multiple chances to "stumble and recover". That is, if students are unable to demonstrate competency in certain learning outcomes in certain courses, they will be given the time, opportunity, and support to address those areas of weakness before there are any permanent repercussions.

While not evident in the structure of the program, it is an important programmatic objective that higher levels of competency be achieved by students in the new first year.
Indeed, we frequently refer to "first year graduate attributes". The Top Ups allow for this approach. But they will also allow students who have met the basic competencies to achieve better results, if they so choose. This will involve self-assessments of strengths and weaknesses, prioritization, and time management skills, all of which are important competencies for life-long learning.

\subsection{Enhancing Diversity and Inclusion}

Students from ALL backgrounds should feel welcome in engineering. While engineering is known to attract those strong in the maths and sciences (sometimes by default), it also needs to more broadly attract those interested in solving problems to help people. A more diverse curriculum can do a better job of showing that side of the profession. The curriculum will be more applied insofar as students can see how theory is expressed in practice in all subjects. The FYP will show the many possible career paths of engineers, including heavy industry, tech innovation, research, and teaching. The program will include diversity in projects that students can pursue in design and research and it will embrace different ways of knowing, e.g. oral traditions, which will be seamlessly woven into the curriculum.

Another aspect of inclusion is respect (knowing what it is and how to live it). That will be a recurring theme in the Indigenous Cultural Contextualization and in the Introduction to the Profession courses. From a structural standpoint, enhancing diversity and inclusion means eliminating needless barriers to different groups of potential students. Figure 3 illustrates a major structural aspect of the new FYP: a consistent weekly schedule. What students do week to week will vary, but the timing will remain the same. This will facilitate time management for family, jobs, teams, and other responsibilities by eliminating the possibility of evening or weekend courses.

\begin{tabular}{|c|c|c|c|c|c|}
\hline & Monday & Tuesday & Wednesday & Thursday & Friday \\
\hline $8: 30 \mathrm{AM}$ & \multirow[b]{2}{*}{$\begin{array}{l}\text { Lecture or } \\
\text { Lab }\end{array}$} & \multirow[b]{2}{*}{$\begin{array}{c}\text { Lecture or } \\
\text { Lab }\end{array}$} & \multirow[b]{2}{*}{$\begin{array}{l}\text { Lecture or } \\
\text { Lab }\end{array}$} & \multirow[b]{2}{*}{$\begin{array}{l}\text { Lecture or } \\
\text { Lab }\end{array}$} & \multirow[b]{2}{*}{$\begin{array}{c}\text { Lecture or } \\
\text { Lab }\end{array}$} \\
\hline $\begin{array}{l}9: 00 \mathrm{AM} \\
9: 30 \mathrm{AM}\end{array}$ & & & & & \\
\hline 10:00 AM & \multirow{3}{*}{$\begin{array}{c}\text { Lecture or } \\
\text { Lab }\end{array}$} & \multirow{3}{*}{$\begin{array}{l}\text { Lecture or } \\
\text { Lab }\end{array}$} & \multirow{3}{*}{$\begin{array}{l}\text { Lecture or } \\
\text { Lab }\end{array}$} & \multirow{3}{*}{$\begin{array}{l}\text { Lecture or } \\
\quad \text { Lab }\end{array}$} & \multirow{3}{*}{$\begin{array}{l}\text { Lecture or } \\
\text { Lab }\end{array}$} \\
\hline $10: 30 \mathrm{AM}$ & & & & & \\
\hline 11:00 AM & & & & & \\
\hline \multicolumn{6}{|l|}{ 11:30 AM } \\
\hline \multicolumn{6}{|l|}{ 12:00 PM } \\
\hline 12:30 PM & \multirow{3}{*}{$\begin{array}{l}\text { Lecture or } \\
\quad \text { Lab }\end{array}$} & & \multirow{3}{*}{$\begin{array}{l}\text { Lecture or } \\
\text { Lab }\end{array}$} & & \multirow{3}{*}{$\begin{array}{c}\text { Lecture or } \\
\text { Lab }\end{array}$} \\
\hline 1:00 PM & & \multirow{3}{*}{$\begin{array}{c}\text { Lecture or } \\
\text { Lab }\end{array}$} & & \multirow{3}{*}{$\begin{array}{l}\text { Lecture or } \\
\text { Lab }\end{array}$} & \\
\hline 1:30 PM & & & & & \\
\hline 2:00 PM & \multirow{3}{*}{$\begin{array}{c}\text { Lecture or } \\
\text { Lab }\end{array}$} & & \multirow{3}{*}{$\begin{array}{l}\text { Lecture or } \\
\text { Lab }\end{array}$} & & \multirow{3}{*}{$\begin{array}{l}\text { Lecture or } \\
\text { Lab }\end{array}$} \\
\hline 2:30 PM & & \multirow{3}{*}{$\begin{array}{l}\text { Lecture or } \\
\text { Lab }\end{array}$} & & \multirow{3}{*}{$\begin{array}{l}\text { Lecture or } \\
\text { Lab }\end{array}$} & \\
\hline 3:00 PM & & & & & \\
\hline 3:30 PM & & & & & \\
\hline 4:00 PM & & \multirow{2}{*}{$\begin{array}{c}\text { Tutorial } \\
\text { (Optional) }\end{array}$} & & \multirow{2}{*}{$\begin{array}{c}\text { Tutorial } \\
\text { (Optional) }\end{array}$} & \\
\hline 4:30 PM & & & & & \\
\hline 5:00 PM & \multirow{2}{*}{$\begin{array}{c}\text { Tutorial } \\
\text { (Optional) }\end{array}$} & & \multirow{2}{*}{$\begin{array}{c}\text { Tutorial } \\
\text { (Optional) }\end{array}$} & & \multirow{2}{*}{$\begin{array}{c}\text { Tutorial } \\
\text { (Optional) }\end{array}$} \\
\hline 5:30 PM & & & & & \\
\hline
\end{tabular}

Figure 3. Proposed weekly/daily schedule. 


\subsection{Enhanced Life Balance}

Figure 3 is a touchstone for another major theme of the program: enhanced life balance. Engineering is known to be a demanding field. We continue to seek to develop the requisite grit and resilience characteristic of the profession. But that need not preclude happiness, enjoyment, and physical and mental health. The blank spots in Fig. 3 represent breaks. Starting at 11:30 am, there are lunch breaks each day for the entire first year cohort, to facilitate social activities of all types, including events, clubs, games, and physical activity. Likewise, the afternoon breaks build in time for students to work together and help each other, to take a real break, and/or to head home early. Tutorials will be daily occurrences, focused on specific courses, but they will also be optional. Again, self-assessment skills will be developed in terms of judging when help is needed.

Exams illustrate another element of this focus on life balance. Rather than the traditional intensive exam period at the end of term, exams will be staggered throughout the year, and there will be the opportunity to review exams and make them formative evaluations.

It is worth noting that the design objective of reducing weekly contact hours has been met. The existing FYP at USask includes roughly $10 \%$ more contact time than the average for the first year programs at many other major Canadian universities. The proposed program reduces mandatory contact hours (which excludes tutorials and Top Ups) from 26.5 hours to 26 in the first term and from 30 hours to 28 in the second term.

\section{LESSONS LEARNED}

Continuous cycles of refinement of the program proposal have yielded many important lessons for anyone hoping to undertake a similar curriculum renewal project. Much of the learning experienced during Phase II of this project has centered on stakeholder engagement. Appropriate and rigorous stakeholder engagement is a key factor for success on any project, but interactions with some stakeholders on this project have revealed some key lessons worth sharing.

A lesson repeated from our experiences in Phase I of the project is that the inclusion of students as major stakeholders, and consulting with them early in the design process, can provide many benefits to the program development process. Our Committee of Student Advisors on Curriculum Development (CSACD), a group of 20+ students representing all years of undergraduate study and engineering disciplines, has provided unique insights into the impact any curricular changes will have on the student experience. The Committee has identified risks, as seen from the student perspective, associated with a nonconventional timetable. Examples include the fact that missed time in an accelerated course due to an illness may be more difficult to make up than in a traditionally scheduled course. Student concerns around this issue have helped us to focus on finding solutions through the optional tutorial time and Top Up courses. The CSACD has also recently formed sub-committees focused on determining the optimal timing of end-of-day tutorials, topics to be included in the Health and Safety course, and what types of extra-curricular activities can be integrated with the program to improve students' work-life balance.

Another important insight into stakeholder engagement was illuminated when we met with representatives from the eight engineering programs offered at USask. Attempting to better prepare students for study in all of those eight programs with a common first year program is a difficult task. Proper preparation for each of the programs and an easy transition out of first year was one of the filters we applied to our initial constraint-free designs. To do this, we considered the program maps of each of the eight programs. However, upon meeting with representatives of each program, including undergraduate chairs, we found that many were considering the renewed first year an opportunity to update their own programs, including second year courses. These discussions loosened some of the design constraints we had applied, reiterating the importance of early and broad dissemination of project information and follow-up with stakeholders.

We also learned an important communication lesson: understand your stakeholder's communication preferences. As engineers consulting with many non-engineers in various math and science departments in the College of Arts and Science at USask, we relied upon communication tools common to the engineering profession, such as the graphical representation of ideas for discussion. We believed that we had clearly represented our intentions to consult meaningfully and that the draft representations, such as those shown in Figures 1 and 2, were just tools to facilitate discussion. We found out late in the process that many non-engineers believed the commitment of ideas to paper signaled that plans were already finalized and the consultation process was really just a one-way conveyance of information. This partial breakdown in communication of intent may have eroded trust between partners and it necessitated renewed inter-college communication to move the project forward.

In order to align the goals and understanding of both colleges involved in the project, a pair of facilitated retreats were held in early 2019 with leadership and key stakeholders from both Colleges, as well as key administrative units on campus, such as the Registrar's Office. The outcome of these retreats was a common understanding of the goals and challenges of the new FYP in engineering and a shared sense of responsibility to overcome the challenges. This has led to the creation of a Change Management Committee (CMC), separate from those individuals working on the design of the program. The CMC includes leadership from both Colleges and representation from the Office of the Vice-Provost Teaching, Learning and Student Experience. The CMC 
will work with the project Design Committee to solve resourcing challenges, including facility, personnel, and financial constraints, and to facilitate the successful implementation of the program.

\section{CONTINUING WORK}

Work on Phase II of the project began in early 2018. This work has resulted in the proposed program structure presented here. However, it would be remiss to say that Phase II is complete. The iterative design process we have embraced demands that past work be constantly revisited and updated. Putting the "what" of Phase I together with the "how" of Phase II has not only impacted the deliverables of Phase II, but has led to revisions of the deliverables completed in Phase I. Furthermore, as the Change Management Committee works to identify resources and solutions to logistical challenges, they may come up against constraints that are incompatible with the current design. For example, the current schedule relies on the availability of large classrooms $(300+$ seats $)$ at certain times. If these rooms are simply not available when needed, the program schedule and structure will need to be revised accordingly.

Preliminary work on Phase III of the project is also underway. Representatives from all academic departments involved will begin meeting this summer to develop learning outcomes and high-level syllabi for each course. This work will also be iterative and collaborative, as course developers will have to communicate often and openly to unlock the all of the benefits of the coordinated and integrated curriculum we have planned. And of course, developments in the detailed course design process may necessitate revisions to the overall program structure. The sculpture continues to gain finer details and features with every passing revision.

\section{Acknowledgements}

Joel Frey has been funded by the University of Saskatchewan's Curriculum Innovation Fund. We want to thank all of the members of the Committee of Student Advisors on Curriculum Development (CSACD), as well as all of the staff and faculty who have provided input to the project thus far.

\section{References}

[1] Joel B. Frey, Sean Maw, Susan Bens, Bruce Sparling, "Design of a Completely New First Year Engineering Program at the University of Saskatchewan," Proc. 2018 Canadian Engineering Education Association. Paper 150. 2018.
[2] Gregor M. Novak, "Just-in-Time Teaching," New Directions for Teaching and Learning, no. 128, pp. 6373, 2011. Available as of April 24, 2018 from https://onlinelibrary.wiley.com/doi/epdf/10.1002/tl.46 $\underline{9}$

[3] John C. Maxwell, Failing Forward: Turning Mistakes into Stepping Stones for Success. Nashville, TN: Thomas Nelson, 2000, 224 pp. \{ISBN: 978$0785274308\}$

[4] Carrie Johnson, "Faculty Speak on the Impact of Time in Accelerated Courses," The Journal of Continuing Higher Education, vol. 57, no. 3, pp. 149-158, 2009.

[5] Raymond J. Wlodkowski and Theresa N. Westover, "Accelerated Courses as a learning format for adults", Canadian Journal for the Study of Adult Education, vol. 13, no. 1, pp. 11-20, 1999.

[6] Mildred V. Hall, Linda A. Wilson and Michael J. Sanger, "Student Success in Intensive versus Traditional Introductory College Chemistry Courses", Journal of Chemical Education, vol. 89, pp. 11091113, 2012.

[7] Patricia A. Scott and Clifton F. Conrad, "A Critique of Intensive Courses and an Agenda for Research", in Higher Education: Handbook of Theory and Research Volume 8, edited by John C. Smart, New York, NY: Agathon Press, 1992, pp. 411-459.

[8] Shella R. Caskey, "Learning Outcomes in Intensive Courses", The Journal of Continuing Higher Education, vol. 42, no. 2, pp. 23-27, 1994.

[9] Peter Geltner and Ruth Logan, The Influence of Term Length on Student Success. Santa Monica, CA: Santa Monica College, 2001, 53 pp.

[10] Eileen L. Daniel, "A Review of Time-Shortened Courses Across Disciplines", College Student Journal, vol. 34, no. 2, pp. 298- 308, 2000.

[11] Marc Seamon, "Short- and Long-Term Differences in Instructional Effectiveness Between Intensive and Semester-Length Courses", Teachers College Record, vol. 106, no. 4, pp. 852-874, 2004.

[12] University Plan 2025: Strategic Framework and Narrative. Saskatoon, Canada: University of Saskatchewan, 2017, $14 \quad$ pp. Available as of April 24, 2018 from https://www.usask.ca/plan/documents/Approved $\% 20$ University\%20Plan.pdf

[13] Elizabeth A. Kuley, Sean Maw, Terry Fonstad, "Engineering Student Retention and Attrition Literature Review," Proc. 2015 Canadian Engineering Education Association. Paper 41. 2015.

[14] Carol S. Dweck, Mindset: The New Psychology of Success. New York, NY: Random House, 2006, 320 pp. \{ISBN: 978-1400062751\} 